\title{
Diversifikasi Produk Olahan Jamur Tiram untuk Menunjang Perekonomian Masyarakat di Kabupaten Jember
}

\section{(Product Diversification of Oyster Mushroom to Support Community Economy in Jember District)}

\author{
Muhammad Iwan Wahyudi ${ }^{*}$, Bagus Tripama ${ }^{1}$, Henik Prayuginingsih ${ }^{2}$, Taufik Timur Warisaji ${ }^{3}$ \\ 1 Jurusan Agroteknologi, Fakultas Pertanian, Universitas Muhammadiyah Jember, Gumuk Kerang, Karangrejo, Sumbersari, \\ Jember, Jawa Timur 68124 \\ 2 Jurusan Agribisnis, Fakultas Pertanian, Universitas Muhammadiyah Jember, Gumuk Kerang, Karangrejo, Sumbersari, \\ Jember, Jawa Timur 68124 \\ 3 Teknik Informatika, Fakultas Teknik, Universitas Muhammadiyah Jember, Gumuk Kerang, Karangrejo, Sumbersari, \\ Jember, Jawa Timur 68124. \\ *Penulis Korespondensi: iwan.wahyudi@unmuhjember.ac.id \\ Diterima Juli 2020/Disetujui Februari 2021
}

\begin{abstract}
ABSTRAK
Kegiatan Program Kemitraan Masyarakat Stimulus (PKMS) bertujuan untuk membantu petani jamur tiram di Jember dengan meningkatkan keterampilan dan pengetahuan dalam diversifikasi pengolahan jamur tiram, membangun jaringan dan pasar, stimulasi modal, dan perbaikan manajerial usaha yang merupakan permasalahan utama mitra dalam mengembangkan usaha dan perekonomian mereka. Metode kegiatan PKMS menggunakan capacity building dengan pendekatan community driven development yang berpijak pada aktivitas yang bersifat kognitif, afektif, dan psikomotorik dalam rangka added value product dan manajemen usaha jamur tiram termasuk pemasaran didalamnya untuk peningkatan pendapatan dan perekonomian mitra. Hasil PKMS berupa peningkatan keterampilan mitra dalam pengolahan jamur tiram menjadi 5 produk yang prospektif dan dibutuhkan pasar. Selain itu, peningkatan keterampilan dalam manajemen usaha mulai perencanaan, mengorganisir anggota mitra, evaluasi kualitas produk, pembukuan sederhana, dan pembukaan akses pasar online/offline serta penguatan modal dalam pengadaan sarana prasarana produksi merupakan keluaran berikutnya dari kegiatan pengabdian yang dilaksanakan. Program ini telah mampu memecahkan permasalahan mitra dalam peningkatan keterampilan diversifikasi pengolahan jamur tiram menjadi produk olahan yang memiliki prospek tinggi di pasar. Perbaikan manajemen usaha dan akses pasar baru khususnya online serta suntikan modal menjadi energi segar bagi mitra dan anggotanya untuk mengembangkan usaha dan perekonomian mereka.
\end{abstract}

Kata kunci: diversifikasi, jamur tiram, kemitraan, produk olahan

\begin{abstract}
The Stimulus Community Partnership Program (SCPP) activities aims to support oyster mushroom farmers in Jember by improving skills and knowledge for diversifying oyster mushroom processing, building networks and markets, stimulating capital, and improving business managerial which are the main problems of partners in developing their businesses and economies. The SCPP activity method uses capacity building with a community driven development approach which is based on activities that are cognitive, affective, and psychomotor in the context of added value products and oyster mushroom business management including marketing to increase income and partner economy. The results of SCPP are in the form of improving partners' skills in processing oyster mushrooms into 5 prospective products that are needed by the market. In addition, increasing skills in business management starting from planning, organizing partne $r$ members, evaluating product quality, simple bookkeeping, opening online/offline market access as well as strengthening capital in the procurement of production infrastructure are the next outputs of the service activities carried out. This program has been able to solve partner problems in improving the skills of diversifying oyster mushroom processing into processed products that have high prospects in the market. Improved business management and access to new markets, especially online, as well as injections of capital into fresh energy for partners and members to develop their businesses and economies.
\end{abstract}

Keywords: diversification, oyster mushrooms, partnership, processed products 


\section{PENDAHULUAN}

Jamur tiram (Pleurotus $s p$ ) merupakan salah satu produk pertanian yang memiliki prospek dan nilai ekonomi cukup tinggi. Saat ini budi daya jamur tiram banyak dilakukan petani seiring dengan banyaknya permintaan pasar baik dalam maupun luar negeri (Sitompul et al.2017). Kabupaten Jember menjadi salah satu sentra produksi jamur tiram selain Yogyakarta, Solo, dan Malang. Jamur tiram yang berasal dari Indonesia sudah merambah ke Jepang dengan volume 90 ton/bulan (Septian, 2019). Terbukanya pasar jamur tiram baik di dalam maupun luar negeri ternyata tidak inline dengan pendapatan yang diperoleh petani jamur itu sendiri. Menurut hasil penelitian Zikri et al. (2015) bahwa RCR budi daya jamur tiram hanya mencapai 1,38 dalam jangka waktu 4-5 bulan. Kondisi kurang menguntungkan ini juga terjadi pada mitra Program Kemitraan Masyarakat Stimulus (PKMS) di Desa Cangkring, Kabupaten Jember.

Rendahnya pendapatan petani jamur secara umum disebabkan oleh nilai produk yang tidak terlalu tinggi di pasar (10.000-12.000/Kg) dan produksi per baglog yang masih relative rendah $(0,3-0,4 \mathrm{~kg} / \mathrm{baglog})$. Rendahnya nilai produk jamur tiram bisa ditingkatkan salah satunya dengan pengolahan jamur tiram menjadi produk yang lebih bernilai tinggi seperti keripik jamur, pepes, nugget, abon, dan sate jamur dengan kemasan yang menarik (value added). Sedangkan produktivitas jamur per baglog bisa ditingkatkan melalui penggunaan nutrisi dan zpt yang bisa dipenuhi melalui riset yang berkesinambungan. Selain masalah di atas, adanya persaingan antar produsen jamur tiram yang tidak sebanding dengan volume permintaan(over supply), belum adanya organisasi yang kuat antar produsen, permodalan, manajemen usaha, dan akses pasar yang lemah, serta minimnya pengetahuan dan keterampilan untuk diversifikasi produk olahan jamur tiram, turut serta menjadi permasalahan yang membatasi perkembangan usaha petani jamur tiram.

Kreativitas dalam upaya meningkatkan nilai jual suatu komoditi mutlak diperlukan termasuk oleh sektor UMKM jamur tiram. Adanya kondisi harga bahan mentah jamur tiram yang cenderung stagnan dan terbatas memerlukan sentuhan teknologi untuk meningkatkan nilainya menjadi produk olahan yang prospektif. Menurut pendapat Cahyono (2019) mengindikasikan bahwa betapa lemahnya kemampuan pelaku UMKM di Kabupaten Jember termasuk pelaku usaha budi daya jamur tiram sebagai salah satu pelaku ekonomi kreatif (industri kreatif) yang sejatinya prospektif sesuai dengan potensi sumber daya lokal. Indikasi yang tampak antara lain daya saing produk belum mampu bersaing dengan produk luar daerah. Artinya pemasaran produk industri kreatif lokal mengalami permasalahan mendasar akibat kompetensi yang dimiliki pelaku masih terbatas. Pendapat Cahyono (2019) ini semakin menegaskan bahwa konstelasi permasalahan pengangguran di perdesaan seperti yang dialami oleh kebanyakan para wanita tani di lokasi sasaran dapat diatasi oleh kemampuan pelaku usaha termasuk pengusaha skala mikro (rumah tangga) untuk membuka kesempatan kerja baru melalui inovasi dan ide-ide kreatifnya.

Berdasarkan kondisi tersebut, diperlukan rangsangan kreatifitas melalui kegiatan pelatihan keterampilan untuk meningkatkan skill pelaku usaha dan kelompoknya dalam diversifikasi produk olahan jamur tiram. Diversifikasi produk olahan jamur tiram memiliki prospek pasar yang cukup bagus karena jamur mudah diolah menjadi makanan dan minuman yang mampu meningkatkan nilai jualnya serta dapat memperluas pemasaran untuk menjaring lebih banyak konsumen (Tjokrokusumo et al. 2015). Banyak produk olahan dari jamur tiram yang sudah dibuat dan teruji rasanya seperti burger jamur titam (Tjokrokusumo et al. 2015), nugget dan abon jamur tiram (Annisa 2017; Astuti et al. 2018), dan keripik jamur tiram (Nugraheni et al. 2014).

Selain itu, adanya kesulitan dalam permodalan terkait pengadaan sarana dan prasarana produksi dapat diatasi dengan stimulus modal melalui PKMS LPPM Universitas Muhammadiyah Jember. Faktor pembatas yang tidak kalah pentingnya untuk diminimalisir, yaitu lemahnya manajemen usaha dan akses pasar. Manajemen usaha yang diawali dengan good planning, organisasi dan link yang kuat, pengawasan kualitas produk, dan pembukuan keuangan yang memadai akan membantu pengusaha jamur tiram dalam pengembangan usahanya. Sedangkan lemahnya akses pasar dari sebagian besar produsen jamur saat ini diperlukan upaya dari berbagai pihak untuk membantu menghubungkan dengan konsumen baik secara online maupun offline. Tujuan kegiatan pengabdian masyarakat ini adalah untuk meningkatkan keterampilan dan pengetahuan mitra dalam pengolahan jamur tiram dengan manajemen usaha yang lebih baik melalui stimulus permodalan dan akses pasar yang mendukung distribusi produk olahan tersebut. 


\section{METODE PELAKSANAAN KEGIATAN}

\section{Lokasi dan Partisipan Kegiatan}

Kegiatan pengabdian masyarakat yang dikemas dalam Program Kemitraan Masyarakat Stimulus (PKMS) ini dilaksanakan di Desa Cangkring, Kecamatan Jenggawah, Kabupaten Jember selama 9 bulan atas kerja sama LPPM Universitas Muhammadiyah Jember dengan petani jamur tiram sebagai mitra. Kegiatan diikuti oleh sebanyak 12 peserta yang akan menjadi tim dari mitra.

\section{Alat dan Bahan}

Bahan utama yang digunakan dalam pelatihan pengolahan jamur tiram adalah jamur tiram segar dan berbagai bahan serta alat penunjang sederhana. Sedangkan untuk peningkatan manajerial dan pemasaran menggunakan modul dan materi praktis yang disiapkan tim PKMS. Stimulus permodalan menggunakan sebagian dana sisa dari proses pelatihan.

\section{Metode Pelaksanaan Kegiatan}

Secara garis besar untuk mencapai tujuan kegiatan dilakukan beberapa tahapan kegiatan yang meliputi sosialisasi dan pelatihan pengolahan jamur tiram (Tabel 1), pendampingan dalam manajemen usaha dan pemasaran, serta stimulasi permodalan.

Adapun kesepakatan yang dilakukan untuk menyelesaikan permasalahan mitra melalui beberapa pendekatan sebagai berikut: pen- dekatan partisipatif (parisipatory) dan pemberdayaan (Community Development) dalam peningkatan keterampilan pengolahan jamur tiram. Upaya penguatan kapasitas SDM sasaran dalam aspek manajemen usaha dan pemasaran, maka dilakukan pendekatanya melalui pelatihan model participatory dan pendampingan selama program PKMS ini berlangsung baik oleh tim pelaksana dibantu dua orang tenaga pendamping mahasiswa. Pelaksanaan pelatihan dilaksanakan secara andragogis (pendidikan orang dewasa) dan bersifat kognitif, afektif, dan psikomotorik. Evaluasi tingkat keberhasilan kegiatan dilakukan dengan metode interview dan observasi dengan membandingkan kondisi sebelum dan setelah kegiatan dari item yang menjadi tujuan kegiatan.

Beberapa langkah yang harus ditempuh dalam program PKMS ini adalah:

- Tahap I: sosialisasi dan rekayasa teknologi, yaitu tahapan penguatan kapasitas SDM pengrajin produk olahan jamur tiram melalui desiminasi dan pelatihan teknis aplikasi inovasi teknologi baru/Teknologi Tepat Guna (TTG) berupa alat untuk proses produksi kerajinan produk olahan jamur tiram

- Tahap II: rekayasa sosial, yaitu tahapan penguatan kapasitas SDM pengrajin pembuatan produk olahan jamur tiram melalui pelatihan manajemen usaha dan pemasaran

- Tahap III: aplikasi TTG, manajemen usaha, dan pemasaran melalui proses pendampingan dan supervisi di lapangan selama pelaksanaan program PKMS ini berlangsung untuk men-

Tabel 1 Tahapan sosialisasi dan pelatihan pengolahan jamur tiram

\begin{tabular}{l} 
Uraian tahapan kegiatan \\
\hline Inventarisasi peralatan untuk pengadaan \\
Menetapkan spesifikasi pada alat yang sudah \\
terinvetarisir \\
Survei harga peralatan sesuai dengan spesifikasi \\
yang telah ditetapkan
\end{tabular}

Pelatihan packaging produk untuk berbagai ukuran dan bentuk sesuai selera pasar

Desiminasi aplikasi inovasi teknologi baru

Pendampingan (supervisi) selama pelaksanaan program PKMS
Metode pendekatan yang ditawarkan

Dilakukan secara partisipasif (PRA) antara tim pelaksana dan mitra guna memeroleh data yang akurat sesuai dengan permasalahan teknis produksi yang dihadapi

Dilakukan secara bersama-sama agar intervensi TTG pada mitra dapat berdaya dan berhasil guna

Melakukan survei harga bersama terhadap peralatan pembuatan produk olahan jamur tiram agar terbangun saling kepercayaan antara tim pelaksana dan mitra

Tutorial dan praktik langsung

Diadakan kegiatan desiminasi untuk mengintroduksi secara teknis kepada mitra dalam mengoperasionalkan alat yang dibutuhkan dalam usaha kerajinan mitra termasuk teknis packaging produk. Tim pelaksana melibatkan instruktur yang berkompeten dalam aplikasi inovasi teknologi baru

Tim pelaksana melibatkan mahasiswa untuk melakukan supervisi dan pendampingan guna menjamin aplikasi TTG dapat berlangsung dengan baik 
jamin aplikasi TTG, manajemen usaha dan pengembangan strategi pemasaran dilakukan secara benar

- Tahap IV: monitoring, evaluasi, dan pelaporan, yaitu proses pengawasan di lapangan selama proses pelaksanaan program PKMS dan melakukan proses penilaian capaian kinerja dengan mengkomparasikan aspek jumlah dan kualitas produksi, tingkat efisinesi biaya, keuntungan, dan pembukuan (laporan keuangan/neraca rugi laba) antara sebelum dengan sesudah pelaksanaan program terhadap standar yang disepakati bersama antara tim pelaksana dengan mitra.

Sementara itu kegiatan monitoring, evaluasi, dan pelaporan meliputi kegiatan berikut ini: 1) Kelompok pengrajin produk olahan jamur tiram bersama tenaga pendamping dari perguruan tinggi menyusun perencanaan, melaksanakan pendampingan, monitoring, dan evaluasi terhadap pelaksanaan program pengabdian termasuk dalam penyusunan jadwal kegiatan; 2) Mengupayakan pihak Disperindag dan Diskop UMKM Kabupaten Jember untuk dilibatkan dalam koordinasi dengan perguruan tinggi dalam melaksanakan pendampingan dan monev di lapangan. Diharapkan pihak pemerintah itu dapat memberikan pembinaan secara berkelanjutan kepada pelaku kerajinan produk olahan jamur tiram (mitra); dan 3) Mitra menyusun laporan kegiatan selama proses produksi berlangsung.

\section{HASIL DAN PEMBAHASAN}

Rangkaian kegiatan yang telah dilakukan untuk mencapai tujuan PKMS adalah meliputi persiapan program bersama mitra, sosialisasi terhadap mitra dan anggotanya, pelaksanaan pelatihan pembuatan olahan jamur, pelatihan dan pendampingan manajerial sederhana, serta mendorong pemasaran secara online dan offline.

\section{Persiapan Pelaksanaan Program}

Persiapan pelaksanaan kegiatan pengabdian masyarakat dilaksanakan melalui beberapa tahapan yaitu berkordinasi dengan tim pelaksana, kordinasi dengan mitra, dan pengadaan sarana prasarana pelatihan. Kordinasi dengan mitra meliputi penjelasan detail tujuan dan gambaran umum program pengabdian, pembahasan waktu yang tepat untuk pelaksanaan kegiatan pelatihan, menentukan tempat dan skenario pelaksanaan kegiatan, menentukan pemateri dan peserta, serta tindak lanjut kegiatan pascapelatihan teknik termasuk manajemen usaha khususnya pembukuan sederhana dan pemasaran. Kegiatan berikutnya setelah diskusi dengan mitra adalah pengadaan sarana dan prasarana pelatihan. Tahapan ini melibatkan sepenuhnya mitra bersama beberapa peserta dan mentor dengan pengawasan dari tim pelaksana (Gambar 1). Hasil tahapan kegiatan ini adalah adanya planning yang matang untuk kegiatan sosialisasi dan pelatihan produk olahan jamur, teknik pelatihan dan pendampingan manajerial terhadap mitra, dan proses pemasaran yang akan di jalankan.

\section{Pelaksanaan Sosialisasi PKMS Produk Olahan Berbasis Jamur Tiram}

Kegiatan sosialisasi diawali dengan pengarahan dari tim pelaksana terkait maksud dan tujuan kegiatan pelatihan, yaitu untuk pemberdayaan masyarakat dalam peningkatan keterampilan dalam pengolahan jamur tiram sebagai salah satu upaya meningkatkan perekonomian masyarakat khususnya ibu rumah tangga yang tidak berpenghasilan atau berpenghasilan rendah. Selanjutnya juga disosialisasikan proses pascapelatihan pembuatan produk olahan jamur yang meliputi pelatihan dan pendampingan manajerial terhadap mitra dan upaya pemasaran yang akan dijalankan. Hasil kegiatan sosialisasi ini adalah pemahaman peserta ter-

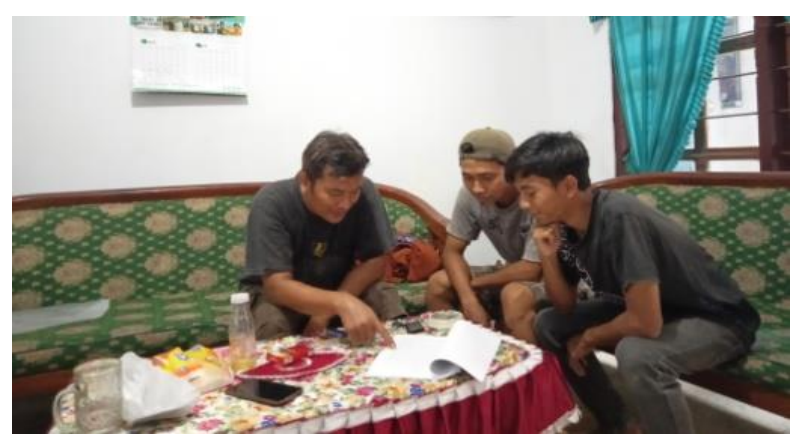

a

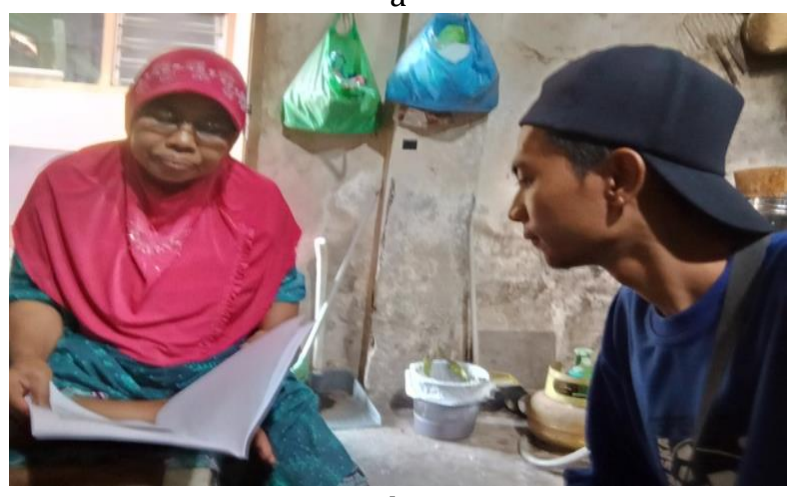

b

Gambar 1 a dan b Kordinasi persiapan tim pelaksana dengan mitra. 
hadap kegiatan pengabdian PKMS dan dibentuk kelompok usaha olahan jamur tiram sebagai upaya untuk kontinuitas program PKMS LPPM Universitas Muhammadiyah Jember. Kesepakatan peserta dan mitra terkait pembentukan kelompok ini diantaranya adalah mitra akan mensuplai bahan baku dan biaya operasional sampai dengan packaging kepada anggota kelompok, kemudian mitra berkewajiban menyalurkan produk dari anggota baik online maupun offline dengan pemotongan cost produksi secara bertahap. Aktivitas lanjutan antara mitra dengan anggota sepenuhnya menggunakan dana pengabdian yang bersumber dari LPPM Universitas Muhammadiyah Jember dan mendapatkan pengawasan serta pendampingan dari tim pelaksana minimal sampai dengan sembilan bulan dari pelaksanaan kegiatan pengabdian.

\section{Pelaksanaan Pelatihan Pembuatan Produk Olahan Berbasis Jamur Tiram}

Kegiatan pelatihan keterampilan dalam pengolahan jamur tiram melibatkan trainer yang berasal dari lingkungan setempat yang memiliki pengalaman dalam pengolahan berbagai masakan termasuk jamur. Teknologi dan resep yang dijalankan merupakan gabungan dari tutorial yang disiapkan oleh tim pelaksana dengan pengalaman mentor sehingga mendapatkan kualitas dan rasa terbaik. Pelatihan keterampilan dalam diversifikasi produk olahan berbahan dasar jamur tiram ini meliputi pembuatan

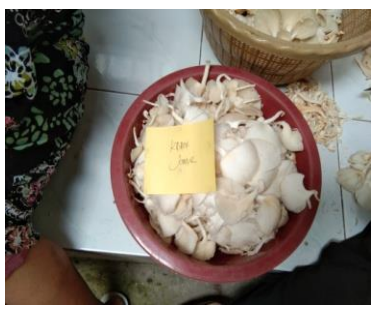

a

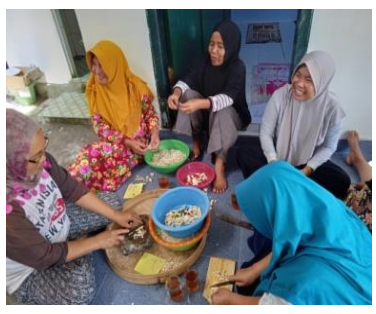

b

keripik jamur tiram, abon jamur, nugget jamur, sate jamur), dan pepes jamur.

Proses pembuatan keripik jamur tiram diawali dengan pemotongan jamur tiram sesuai selera dengan memisahkan antara daun dan batang jamur, selanjutnya setelah dicuci bersih jamur suwiran tersebut dicampur dengan bahan yang telah di siapkan dan bahan siap digoreng dengan api kecil (Gambar 2). Selanjutnya, proses pembuatan abon jamur tiram, yaitu dengan mencincang jamur ukuran lembut setelah dikukus selama kurang lebih 15 menit menyerupai daging. Selanjutnya jamur dihaluskan dan ditekan agar lebih lembut. Langkah berikutnya jamur tiram tersebut di masukkan ke dalam wajan yang telah berisi bumbu dan diaduk hingga kering (Gambar 3).

Pengolahan jamur tiram lainnya, yaitu nugget jamur tiram yang diawali dengan membersihkan jamur tiram lalu peras sampai airnya kering, kemudian jamur tiram diblender dengan campuran air, susu, dan telur. Berikutnya campur semua bahan kecuali tepung roti dan memasukkan adonan ke loyang yang sudah dilapisi plastik. Panaskan dandang masukkan loyang yang sudah diisi adonan dan kukus selama 20 menit. Jika sudah dingin keluarkan dari loyang kemudian cetak menggunakan cetakan sesuai selera. Langkah berikutnya lumuri nugget yang sudah dibentuk dengan telur yang telah dikocok dan dibaluri dengan tepung roti selanjutnya simpan di lemari es selama kurang lebih 1 jam dan nugget siap digoreng (Gambar 4).

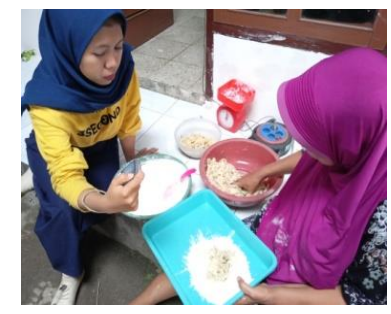

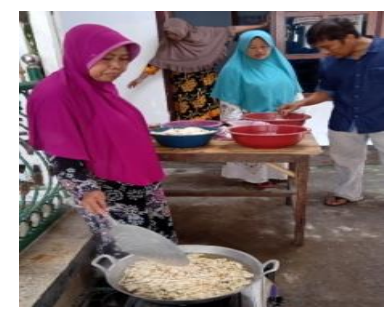

d

Gambar 2 Proses pembuatan keripik jamur tiram: a) Jamur tiram yang masih utuh; b) Pemotongan dan pemisahan daun dan batang jamur tiram, c) Pencampuran dengan bahan lain; dan d) Penggorengan jamur tiram.

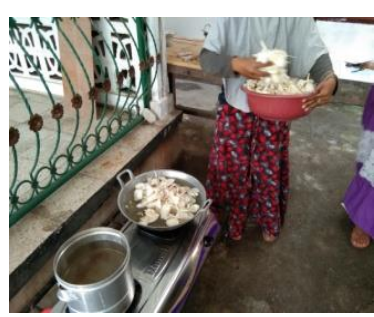

a

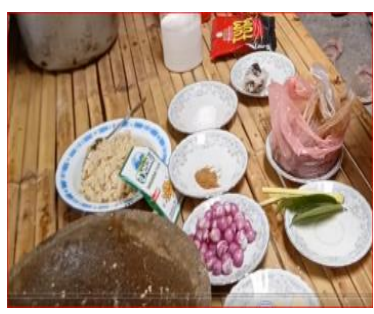

b

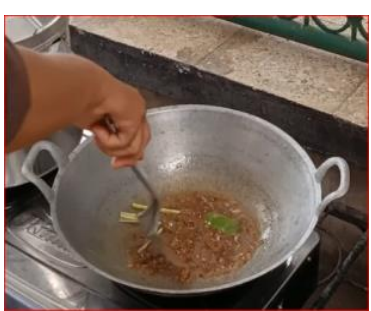

C

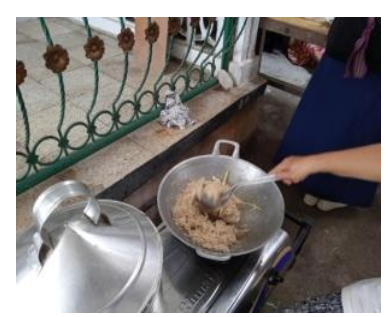

d

Gambar 3 Proses pembuatan abon jamur tiram: a) Pengukusan jamur tiram; b) Bahan-bahan pembuatan abon jamur; c) Proses penumisan bumbu untuk abon; d) Pencampuran jamur ke dalam bumbu. 
Pengolahan jamur tiram berikutnya adalah sate jamur yang dilakukan dengan cara merebus terlebih dahulu jamur tiram yang telah disobek sekitar 15 menit, kemudian menusukkan daging jamur tiram ke sujen dengan 1 lembar jamur untuk tiap sujen. Selanjutnya dilakukan proses pembuatan sate jamur seperti sate pada umumnya (Gambar 5). Pengolahan jamur tiram yang terakhir dalam kegiatan pelatihan ini adalah pepes jamur tiram. Cara pembuatan relatif sederhana, yaitu dengan menyuir daun jamur tiram kemudian mencampurkannya dengan

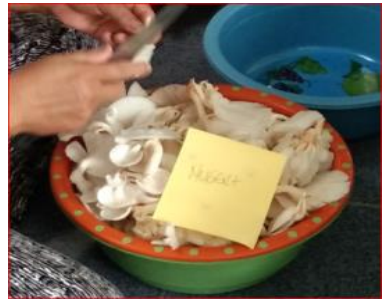

a

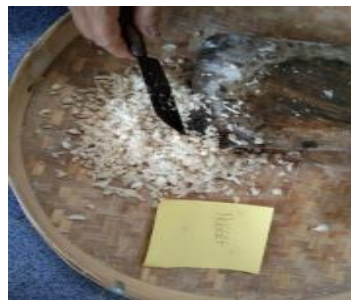

$\mathrm{b}$ bumbu yang telah disiapkan dan selanjutnya di kukus sekitar 30 menit (Gambar 6). Poduk olahan jamur tiram yang sudah jadi dikemas dalam packaging yang menarik seperti pada Gambar 7.

Evaluasi terhadap pelaksanaan pelatihan meliputi ada tidaknya peningkatan pengetahuan dan keterampilan peserta dalam pengolahan jamur tiram menjadi produk olahan yang bernilai ekonomis tinggi. Berikut data peningkatan pengetahuan dan keterampilan peserta sebelum dan setelah pelatihan (Tabel 2). Berdasarkan hasil evaluasi secara umum terjadi peningkatan

Gambar 4 Proses pembuatan nugget jamur tiram: a) Pembersihan jamur tiram; b) Pemotongan jamur tiram; c) Proses penghalusan jamur tiram; dan d) Pencetakan nugget sesuai selera.

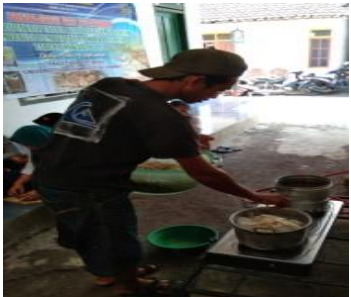

a

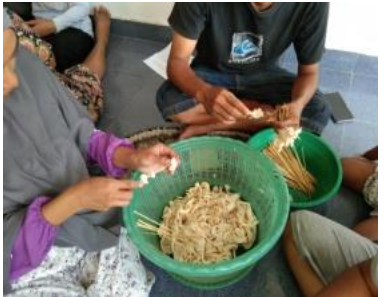

$\mathrm{b}$

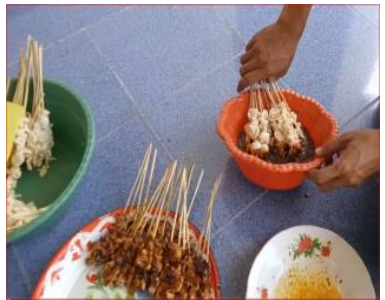

C

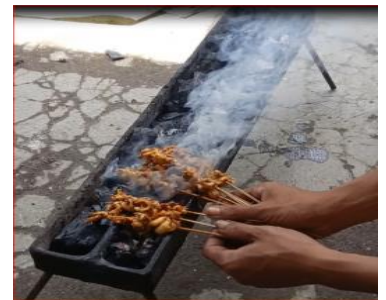

$\mathrm{d}$

Gambar 5 Proses pembuatan sate jamur tiram: a) Perebusan jamur tiram; b) Penusukkan daging jamur tiram ke sujen; c) Pemberian bumbu; dan d) Pembakaran sate jamur tiram.

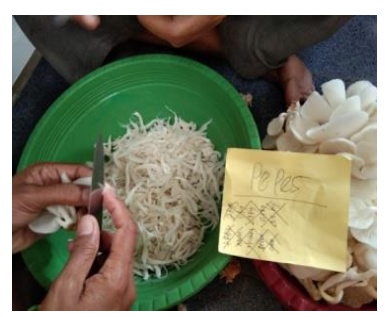

a

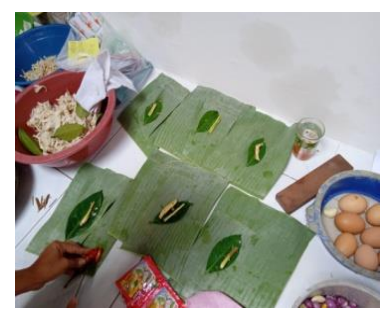

b

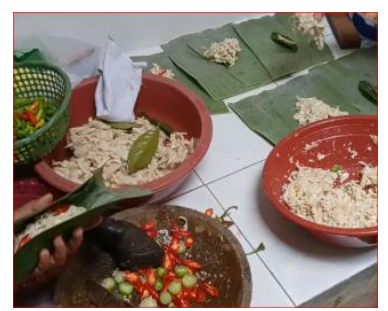

d

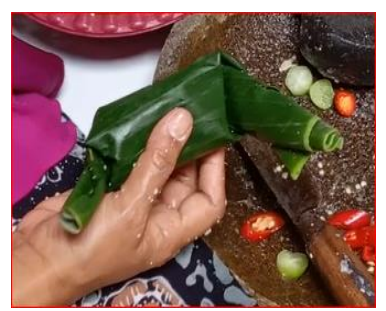

e

Gambar 6 Proses pembuatan pepes jamur tiram: a) Penyuwiran jamur tiram; b) Penyiapin daun pembungkus; c) pencampuran dengan bumbu; dan d) pembungkusan pepes jamur tiram.

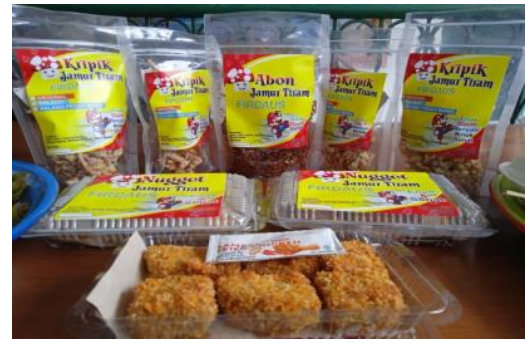

a

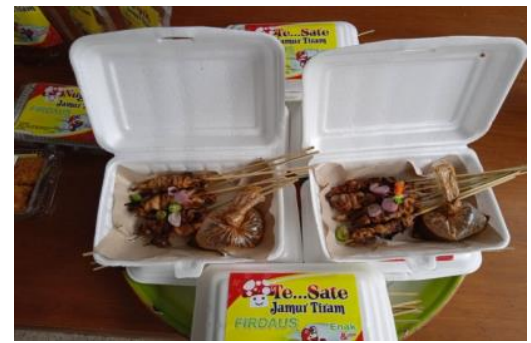

$\mathrm{b}$

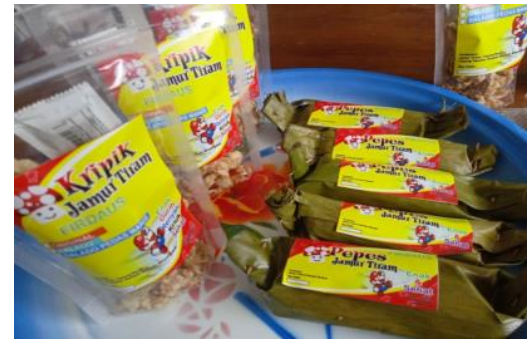

C

Gambar 7 Produk olahan jamur tiram: a) Kripik dan nugget jamur tiram; b) Sate jamur tiram; dan c) Pepes jamur tiram. 
Tabel 2 Hasil evaluasi pelatihan pengolahan jamur tiram

\begin{tabular}{|c|c|c|c|c|c|c|c|}
\hline \multirow[b]{2}{*}{$\begin{array}{l}\text { Uraian } \\
\text { kagiatan }\end{array}$} & \multicolumn{3}{|c|}{ Sebelum pelatihan } & \multicolumn{3}{|c|}{ Sesudah pelatihan } & \multirow[b]{2}{*}{$\begin{array}{c}\text { Peningkatan } \\
\text { keterampilan } \\
\text { (\%) }\end{array}$} \\
\hline & $\begin{array}{l}\text { Jumlah } \\
\text { peserta } \\
\text { (orang) }\end{array}$ & $\begin{array}{c}\text { Jumlah yang } \\
\text { terampil } \\
\text { (orang) }\end{array}$ & $\begin{array}{c}\text { Persentase } \\
\text { keterampilan } \\
(\%)\end{array}$ & $\begin{array}{l}\text { Jumlah } \\
\text { peserta } \\
\text { (orang) }\end{array}$ & $\begin{array}{c}\text { Jumlah yang } \\
\text { terampil } \\
\text { (orang) }\end{array}$ & $\begin{array}{c}\text { Persentase } \\
\text { keterampilan } \\
(\%)\end{array}$ & \\
\hline $\begin{array}{l}\text { Mengolah } \\
\text { keripik jamur }\end{array}$ & 12 & 3 & 25,0 & 12 & 10 & 83,3 & 58,3 \\
\hline $\begin{array}{l}\text { Mengolah abon } \\
\text { jamur }\end{array}$ & 12 & 0 & 0,0 & 12 & 8 & 66,6 & 66,6 \\
\hline $\begin{array}{l}\text { Mengolah } \\
\text { nugget jamur }\end{array}$ & 12 & 0 & 0,0 & 12 & 7 & 58,3 & 58,3 \\
\hline $\begin{array}{l}\text { Mengolah sate } \\
\text { jamur }\end{array}$ & 12 & 5 & 41,6 & 12 & 12 & 100,0 & 58,4 \\
\hline $\begin{array}{l}\text { Mengolah } \\
\text { Pepes Jamur }\end{array}$ & 12 & 0 & 0,0 & 12 & 9 & 75,0 & 75,0 \\
\hline
\end{tabular}

pengetahuan dan keterampilan peserta pelatihan secara signifikan. Hal ini bisa dilihat dari jumlah peserta yang meningkat pengetahuan dan keterampilannya lebih dari $50 \%$ dari total peserta yang mengikuti pelatihan pengolahan jamur tiram. Semakin sulit proses pengolahan maka jumlah peserta yang terampil semakin menurun, begitu juga sebaliknya. Sebagai contoh pengolahan pepes jamur yang relative paling mudah, maka setelah pelatihan $75 \%$ peserta sudah terampil untuk membuatnya. Peserta pelatihan sudah memiliki keterampilan dalam mengolah keripik dan sate jamur masing-masing 25 dan 41,6\% sebelum pelatihan dan meningkat menjadi 83,3 dan $100 \%$ setelah pelatihan. Sedangkan untuk pengolahan jamur tiram menjadi abon, nugget, dan pepes, hampir semua peserta belum bisa melakukannya. Pascapelatihan, ketiga produk olahan tersebut bisa dibuat oleh 66,6; 58,3; dan 75\% dari keseluruhan peserta. Berdasarkan hasil tersebut, tujuan dari pelatihan sudah dianggap berhasil karena terjadi peningkatan jumlah tenaga terampil sebanyak 63,3\%. Apabila peserta pelatihan bisa konsisten untuk mengasah kemampuan mereka dan kontinu untuk membuat produk olahan dan mentransfer teknologi kepada yang lain, maka tingkat keberhasilan program pengabdian ini kan lebih baik lagi.

\section{Manajemen Usaha dan Pemasaran Produk Olahan Jamur Tiram}

Tim pelaksana bertindak sebagai pendamping dan pemberi saran mitra dalam hal planning pengadaan bahan baku, sistematika organisasi kelompok, pengelolaan keuangan, dan pemasaran. Pengadaan bahan baku jamur tiram dilakukan secara mandiri (produksi sendiri) oleh mitra melalui dana PKMS LPPM Universitas
Muhammadiyah Jember. Hal ini akan menurunkan cost produksi hingga 100\% apabila bahan baku didapatkan dari pasar. Selanjutnya pengorganisasian dengan anggota mitra yang terbentuk setelah pelatihan dilakukan dengan system kemitraan, dimana mitra memberikan fasilitas bahan baku dan bahan pendukung produksi. Anggota kelompok kemudian memproses produk olahan jamur tiram sesuai pesanan dan di jual kepada mitra dengan pemotongan modal yang telah diberikan mitra sebelumnya. Cash flow dari aktivitas ini dibukukan dalam bentuk pembukuan sederhana oleh mitra sehingga pergerakan usaha bisa di tracking perkembangannya. Sedangkan untuk pemasaran, tim pelaksana mencoba untuk membuka pasar terutama secara online baik melalui grup whatsapp, status whastapp, market place di facebook, tokopedia, dan tanihub (Gambar 8). Selain itu, tim pelaksana juga membantu mitra untuk menentukan harga (pricing) yang paling ideal agar bisa bersaing di pasaran.

Satu minggu dari pelatihan pesanan sudah mulai berdatangan mulai dari kota Malang, Madiun, Surabaya, dan Majene (Sulawesi Selatan), namun sayangnya proses tersebut hanya bertahan sekitar sebulan dan berakhir seiring terpaan Covid 19 yang mencapai puncaknya pada April 2020. Berdasarkan kondisi pasar online yang telah dijalankan, dari beberapa metode yang dilakukan terdapat beberapa kendala pada market place seperti tokopedia yang belum memiliki transaksi sampai dengan saat ini. Hal ini disebabkan mitra/tim pelaksana menggunakan fasilitas free dan tidak ditingkatkan ke level premium, sehingga konsumen sulit untuk dipertemukan dengan produk yang ditawarkan mitra. Transaksi yang telah 
Pilih semua produk

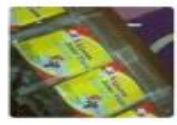

abon jamur tiram $100 \mathrm{gr}$

Stok 10

Rp 26,000

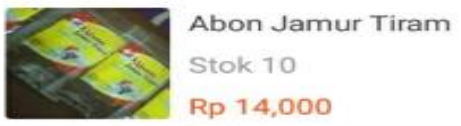

Gambar 8 Contoh promo pemasaran melalui Tokopedia.

dilakukan mayoritas dari grup whatsapp dan market place facebook.

Kunci keberhasilan pemasaran secara online berdasarkan pengalaman trader sukses adalah menempatkan barang pada market place yang terkemuka dan dilakukan secara premium, baik berbayar atau pemberian fee pada provider. Langkah berikutnya adalah secara kontinu mempromosikan barang tersebut di medsos sehingga peluang bertemunya dengan kustomer lebih besar. Hal inilah yang menjadi kendala mitra dalam perdagangan secara online. Berdasarkan kendala tersebut, tim pelaksana akan melakukan evaluasi dan pendampingan untuk pemasaran termasuk membantu pemasaran offline di lingkungan Universitas Muhammadiyah Jember melalui koperasi.

Secara garis besar telah terjadi peningkatan keterampilan mitra dalam manajemen usaha dan pembukuan sederhana dengan indikasi terbentuknya kelompok kemitraan antara mitra PKMS dengan anggotanya, adanya pembukuan sederhana yang didampingi oleh Tim pendamping LPPM UM Jember. Begitu juga dalam hal pemasaran, mitra memiliki peningkatan keterampilan untuk memasarkan produk lebih luas baik secara online maupun offline dari sebelumnya yang hanya dipasarkan disekitar rumah mitra. Selain itu, program PKMS juga meningkatkan permodalan mitra yang dikelola secara bergulir untuk para anggotanya.

\section{SIMPULAN}

Program PKMS melalui pelatihan diversifikasi produk olahan jamur tiram telah membantu memecahkan permasalahan teknis pengolahan produk berbasis jamur tiram dengan indikasi adanya peningkatan pengetahuan dan keterampilan dalam peningkatan value produk olahan jamur tiram. Program PKMS mampu meningkatan keterampilan dalam manajemen usaha dan pemasaran yang baik untuk memperbesar peluang peningkatan kesejahteraan mitra dan anggotanya. Mitra bersama tim pelaksana telah melaksanakan upaya pemasaran baik online dan offline meskipun mendapati kendala karena ditengarai adanya covid 19. Permodalan yang menjadi kendala utama mitra bisa diatasi dengan program PKMS yang akan dilanjutkan dengan perputaran modal yang telah ada ditambah dengan sumber lain dari mitra dan anggota secara mandiri.

Perlu adanya pendampingan komprehensif dan berkelanjutan dari mitra PKMS Universitas Muhammadiyah Jember sehingga menjadi salah satu pilar kuat dalam pengembangan institusi dan umat. Institusi melalui LPPM hendaknya membantu membuka akses dalam peningkatan entrepreneur mitra melalui pasar baik online maupun offline bahkan untuk pasar luar negeri. Institusi hendaknya lebih cepat dan banyak untuk menciptakan teknologi baru bagi mitra khususnya untuk percepatan peningkatan perekonomian masyarakat dan kemajuan institusi.

\section{UCAPAN TERIMA KASIH}

Terima kasih yang sebesar-besarnya kepada Lembaga Penelitian dan Pengabdian Kepada Masyarakat (LPPM) Universitas Muhammadiyah Jember atas dana hibah sehingga kegiatan ini terlaksana. Ucapan yang sama terhadap tim pelaksana dan mitra serta pihak terkait di wilayah Desa Cangkring, Kecamatan Jenggawah, Kabupaten Jember.

\section{DAFTAR PUSTAKA}

Annisa N. 2017. Diversifikasi Produk Olahan Jamur (Pleurotus Ostreatus) Sebagai Peningkatan Pengetahuan Keterampilan Dalam Upaya Mendukung Hidup Sehat : Studi Kasus RW 05 Desa Cipacing-Jatinangor. Dalam: Prosiding Penelitian dan Pengabdian kepada Masyarakat. Desember 2017. Halaman: 390-447. https://doi.org/10. 24198/jppm.v4i3.15718

Astuti S, Suharyono, Affandi MI. 2018. Pelatihan Diversifikasi Produk Olahan Kaya Gizi Pada Kelompok Budidaya Jamur Tiram Di Desa 
Sidosari Kecamatan Natar Kabupaten Lampung Selatan. Dalam: Prosiding Seminar Nasional Penerapan IPTEKS. Lampung (ID): Politeknik Negeri Lampung 08 Oktober 2018. Hal: 95-100.

Cahyono D. 2019. Revitalisasi Enterpreneurship Terhadap Pelaku Industri Kreatif Berbasis Kinerja Balance Scorecard. Jurnal Manajemen dan Bisnis Indonesia. 5(1): 121-134.

Nugraheni M, Hera WHT, Utama A. 2014. Teknologi Pengolahan Produk Berbasis Jamur di Kawasan Rawan Bencana Erupsi Merapi. INOTEKS. 18(2): 177-192.

Septian F. 2019. Analisa Usaha Budi daya Jamur Tiram 1000 Baglog. [Internet]. [Diakses pada: tanggal 15 Desember 2019]. Tersedia pada: https://erakini.com/analisa-usaha-budidayajamur/
Sitompul FT, Zuhry E, Armaini. 2017. Pengaruh Berbagai Media Tumbuh dan Penambahan Gula (Sukrosa) terhadap Pertumbuhan Jamur Tiram Putih (Pleurotus ostreatus). Jurnal Online Mahasiswa Fakultas Pertanian. 4(2): 1-15.

Tjokrokusumo D, Widyastuti D, Giarni R. 2015. Diversifikasi produk olahan jamur tiram (Pleurotus ostreatus) sebagai makanan sehat. Dalam: Prosiding Seminar Nasional Masyarakat Biodiversity Indonesia. Desember 2015: Hal: 2016-2020. https://doi.org/10. $13057 / \mathrm{psnmbi} / \mathrm{m} 010828$

Zikri AR, Khaswarina S, Maharani E. 2015. Analisa Usaha dan Pemasaran Jamur Tiram Putih (Pleurotus Ostreatus). Studi Kasus di Kelurahan Tangkerang Kecamatan Tenayan Raya Kota Pekanbaru. Jurnal Online Mahasiswa Fakultas Pertanian. 2(2): 1-10. 